\title{
1 Radium dial watches, a potentially hazardous legacy?
}

2 Authors.

*Gavin K. Gillmore, Centre for Earth and Environmental Sciences Research, School of

4 Geography, Geology and the Environment, Kingston University, Penrhyn Road,

$5 \quad$ Kingstonupon-Thames, Surrey, KT1 2EE. Tel: 0044 (0)20 84172518.

6 Email: G.Gillmore@kingston.ac.uk.

7 Robin Crockett, School of Science and Technology, University of Northampton,

$8 \quad$ Northampton, NN2 6JD. Tel: 0044 (0)1604 893107.

$9 \quad$ Email: robin.crockett@northampton.ac.uk.

Tony Denman, School of Science and Technology, University of Northampton, Northampton,

NN2 6JD. Tel: 0044 (0)1604 735500.

12 Email: Tony.Denman@,northampton.ac.uk.

Alan Flowers, School of Mechanical and Automotive Engineering, Kingston University,

Penrhyn Road, Kingston-upon-Thames, Surrey, KT1 2EE. Tel: 0044 (0)20 84172486.

Email: A.Flowers@kingston.ac.uk.

Richard Harris, Technical Support, Faculty of Science, Engineering and Computing,

17 Kingston University, Penrhyn Road, Kingston-upon-Thames, Surrey, KT1 2EE. Tel: 0044

$18 \quad(0) 2084172625$.

Email: R.Harris@kingston.ac.uk.

*Corresponding author. 
Abstract.

This study re-examines the risk to health from radium $\left({ }^{226} \mathrm{Ra}\right)$ dial watches. Ambient dose equivalent rates have been measured for fifteen pocket watches giving results of up to $30 \mu \mathrm{Sv}$ $\mathrm{h}^{-1}$ at a distance of $2 \mathrm{~cm}$ taken with a series 1000 mini-rad from the front face (arithmetic mean ambient dose equivalent for pocket watches being $\left.13.2 \mu \mathrm{Sv} \mathrm{h}^{-1}\right)$. A pocket compass gave rise to a similar ambient dose equivalent rate, of $20 \mu \mathrm{Sv} \mathrm{h}^{-1}$, to the pocket watches, with its cover open. Eighteen wristwatches have also been assessed, but their dose rates are generally much lower (the arithmetic mean being $3.0 \mu \mathrm{Sv} \mathrm{h}^{-1}$ ), although the highest ambient dose equivalent rate noted was $20 \mu \mathrm{Sv} \mathrm{h}^{-1}$. A phantom experiment using a TLD suggested a shallow dose equivalent of $0.36 \mathrm{mSv}$ for 40 days exposure (dose rate $0.375 \mu \mathrm{Sv} \mathrm{h}^{-1}$ ). We estimated maximum skin dose for our pocket watches as $16 \mathrm{mSv}$ per year assuming the watch was worn for 16 hours / day throughout the year, with effective doses of $5.1 \mathrm{mSv}$ and 1.169 $\mathrm{mSv}$ when worn in vest and trouser pockets respectively. This assumes exposure from the back of the watch which is generally around $60-67 \%$ of that from the front. The maximum skin dose from a wristwatch was $14 \mathrm{mSv}$, with $4.2 \mathrm{mSv}$ effective dose in vest pocket. Radium $\left({ }^{226} \mathrm{Ra}\right)$ decays to the radioactive gas radon $\left({ }^{222} \mathrm{Rn}\right)$, and atmospheric radon concentration measurements taken around a pocket watch in a small sealed glass sphere recorded $18,728 \mathrm{~Bq} \mathrm{~m}^{-3}$. All watches were placed in a room with a RAD7 real-time radon detector. Radon concentration average was $259 \pm 9 \mathrm{~Bq} \mathrm{~m}^{-3}$ over 16 hours, compared to background average over 24 hours of $1.02 \mathrm{~Bq} \mathrm{~m}^{-3}$. Over 6 weeks highs in the order of 2,000 $\mathrm{Bq} \mathrm{m}{ }^{-3}$ were routinely recorded when the ventilation system in the room was operating at reduced rates, peaking at over $3,000 \mathrm{~Bq} \mathrm{~m}^{-3}$ on several occasions. Estimates of the activity of 
$44 \quad{ }^{226} \mathrm{Ra}$ in the watches ranged from 0.063 to $1.063 \mu \mathrm{Ci}(2.31$ to $39.31 \mathrm{kBq})$ for pocket watches and from 0.013 to $0.875 \mu \mathrm{Ci}(0.46$ to $32.38 \mathrm{kBq})$ for wrist watches. The risk from old watches containing radium appears to have been largely forgotten today. This paper indicates a health risk, particular to collectors, but with knowledge and appropriate precautions the potential risks can be reduced.

Key words: Radium, radon, watches, health risks.

\section{Introduction.}

In 1977 the National Council on Radiation Protection and Measurements in the USA published a report (NCRP, 1977) on radiation exposure from consumer products. In that report they commented on radiation dose from radioluminescent paints, in particular watch and clock dials. This paint consisted of crystalline phosphorescent zinc sulphide (ZnS) with the addition of radium $\left({ }^{226} \mathrm{Ra}\right.$, half-life of 1600 years $)$, mesothorium $\left({ }^{228} \mathrm{Ra}\right.$, half-life of 5.8 years) and radiothorium $\left({ }^{228} \mathrm{Th}\right.$, half-life of 1.9 years $)$ in the form of insoluble sulphates (Martland and Humphries, 1973). The NCRP (1977) report was recently updated by the work of Boerner and Buchholz (2007), in a scoping study for the US Nuclear Regulatory Commission (NRC). Shaw et al. (2007) have also recently produced guidelines for the control of consumer products containing radioactive materials for the European Union.

In our study, we have looked again at dose from such objects in the light of current understanding of dose and exposure risk. Radium $\left({ }^{226} \mathrm{Ra}\right)$ activated dial watches (pocket and wristwatches) are still in circulation, although not to the extent they were in the 1970s when there was estimated to be over 10 million watches in the USA with luminous ${ }^{226} \mathrm{Ra}$ dials (NCRP, 1977). Indeed, such watches have become collectors' items in their own right and 
67 are sought through commercial and personal internet sites for example (Boerner and

68

69

Buchholz, 2007), although many amateur collectors are unaware of the dangers of

radioluminescent materials. These dangers might not be insignificant given the

radioactivities encountered, e.g. according to Blaufox (1988) some watches contained as much as $4.5 \mu \mathrm{Ci}(167 \mathrm{kBq})$ of radium.

In view of this, we have re-evaluated the risks to collectors and wearers of such items by taking a series of radiation measurements. However, it is important to acknowledge that meaningfully obtaining absolute dose equivalent values arising from wearing personal timepieces is difficult (Frame, 2008). In this paper we quote measured dose rates only indicatively, but note that our values are comparable with those obtained elsewhere (Boerner and Buchholz, 2007).

Radium was produced from pitchblende which according to Cameron (1912) contains 50 to $80 \%$ uranium oxide, with thorium (from traces to $10 \%$ ). In the early $20^{\text {th }}$ Century, it was possible to extract around $3 \mathrm{~g}$ of radium from $30,000 \mathrm{~kg}$ of pitchblende which contained $53 \%$ uranium oxide (Cameron, 1912), with a price of around $£ 20$ per mg. This was described as a great cost at the time. Bizony (2007) suggests that as a result of the high cost of ${ }^{226} \mathrm{Ra}$ production, many luminescent items advertised as containing radium, in fact owed the origin of their luminescence to the use of cheaper mesothorium (mesothorium I or ${ }^{228} \mathrm{Ra}$ ) which had been separated from minerals containing ${ }^{232} \mathrm{Th}$, e.g. monazite sands (Schlundt, 1931; Harvie, 2005). Such lower cost products, using thorium manufactured in the 1930s, will now have less than one thousandth of their original activity because of the much shorter thorium halflife, and hence will have much lower radiological risk than "Radium watches" which contain ${ }^{226} \mathrm{Ra}$. 
Historically, radium has been acknowledged as a significant health hazard. In particular, in the context of this research, it presented a hazard to workers who painted the radium on to the dials and initially licked their brushes, this being an activity which led to necrosis of the mandible and maxilla, bone tumours and jaw-bone porosity (e.g. Evans, 1966; NCRP, 1977; BEIR IV, 1988; Stehney, 1995; Harvie, 2005). After the Second World War, mesothorium was used more than radium, partly due to the involved process in extracting radium and associated costs. However, radium continued to be used until replaced by tritium in the late 1960s following the 1967 IAEA recommendation that its use in pocket watches should cease.

A study of workers in the luminising industry published in 1981 indicated that women under the age of 30 ( $78 \%$ of the workforce) had a significantly raised risk of dying from breast cancer (Harvie, 2005; Bruenger et al., 1994). Bruenger et al. (1994) state that it is not clear whether this is due to internal exposure to radium isotopes or to external radiation from elevated gamma or high radon $\left({ }^{222} \mathrm{Rn}\right)$ in the working environment. Bizony (2007) suggests that at one factory producing radium dials in New Jersey, USA, a hundred workers died as a result of radium poisoning.

The cessation of this industry has lead to a loss of awareness of the radiological risk from devices containing radium. However, some national agencies continue to make efforts to publicise this hazard, e.g. in 2001 the UK Health and Safety Executive (HSE) issued guidelines to local authority enforcement officers regarding hazards from the repair of luminised timepieces (HELA, 2001) and the USA Environmental Protection Agency (EPA) strongly recommends on its web site (http://www.epa.gov/radtown/docs/antiques.html; last accessed $10^{\text {th }}$ February 2012) that radium dial watches are not dismantled. 
In addition to hazards from manufacturing and use, significant hazards from legacy industrial sites may remain. In the UK there are several sites that were never properly remediated that produced such radium products. Harvie (2005) suggests that besides unremediated former uranium and radium mines there are also unremediated former ore-processing and manufacturing sites. Readings of $24 \mu \mathrm{Sv} \mathrm{h}{ }^{-1}$ have been obtained from spoil heaps associated with abandoned mines in Cornwall (Fowler, 2010). Harvie (2005) also notes the site of the former Radium Works in Runcorn, Cheshire, which is now a housing estate, and the presence of a radium-contaminated former Smiths Industries luminising plant neighbouring a school in Wishaw, Lanarkshire. Also, the UK Olympic Park Development Authority noted ambient dose rates of $7 \mu \mathrm{Sv} \mathrm{h}^{-1}$ at one site. This was attributed to soil contaminated by a ${ }^{226} \mathrm{Ra}$ luminised instrument in a 1950s landfill (ODA, 2007).

In a recent soil geochemistry survey by the British Geological Survey of the London area (LondonEarth 2011; see http://www.bgs.ac.uk/gbase/londonearth.html), one anomalous region, currently (as at 2011) an area of light industry and housing, was identified. This had high thorium levels (no tests have been conducted yet for radium) due to its former use as a clock works in the 1920s, followed by an armaments factory until the 1980s. The significance of these findings is currently under investigation. However, the UK problem is relatively minor compared to parts of the USA where the US Radium Dial Corporation (dials for Westclox, amongst others) had plants that both processed the ore and painted dials in Orange, New Jersey.

There remains, therefore, a considerable legacy from in the use of radium and associated radioisotopes both at former and present industrial sites and in consumer products. In this paper we are focussing on one aspect of the consumer product issue, namely radioluminescent pocket and wrist watches. 


\section{i)Description of the watch sample.}

Fifteen pocket watches (numbered P1-15; see Table 1) and eighteen wristwatches (numbered W1-18; see Table 2) selected for measurement were from a variety of manufacturers and countries. All had previously been in private ownership and most were purchased through eBay. Of the pocket watches, seven were Swiss made in the1930s-40s and issued in 19391945. A number of these have UK military G.S.T.P. or General Service Timepiece / Temporary Pattern markings (Wesolowski, 2006) and some are marked 'Bravingtons' being sold by that company after the Second World War as war surplus stock to the public. One military issue pocket watch was a US made black dialled Waltham (P14) marked with a British government broad arrow. This type was issued mostly to the navy, post 1941 (Wesolowski, 2006). Of the civilian pocket watches, one was UK manufactured by the Ingersoll Watch Company and six were US made mostly in the mid-1950s (see Figure 1). Most of the US made pocket watches were produced as 'dollar' watches being cheaply mass produced from stamped out parts and non-jewelled pin-lever movements. Such watches were manufactured from the 1890 s to the mid 1950 s, the most famous being made by the US Ingersoll company who were the first to get the price down to a dollar (Bruton, 2002). This type of watch (P5-11 and P15; Table 1) was selected for this study as being representative of a commonly available pocket watch, and therefore provides an indication of the typical exposure to ${ }^{226} \mathrm{Ra}$ for wearers or collectors. Dollar watches are collectible today, particularly in the USA. The P1-5 and P12-14 (Table 1) pocket watches would have been mid-priced items with good quality jewelled movements, and as military issues are now particularly collectible. 
159 Of the eighteen selected wristwatches two were manufactured in the UK in the 1950s by

160 Newmark (W14-15). This was a watch importing company until it set up a factory in

161 Croydon in 1947 with Smiths and Vickers-Armstrong (Bruton, 2002). This factory ceased

162 operation in 1960, but produced 7 million Newmark watches between 1950 and 1960 . W10

163 (Table 1) was made by Ingersoll UK, probably at the Ystradgynlais factory in Wales which

164 ceased trading in 1969. This was established as the Anglo-Celtic Watch Company after the

165 Second World War, again with Smiths Industries, Vickers and government support. These

166 watches are of some interest to British collectors - although they were cheaply mass

167 produced pin-pallet ones and therefore may be considered the UK low cost equivalent to the

168 USA dollar pocket watches (Bruton, 2002). In addition various Swiss made wristwatches

were assessed (see Table 2, W1, W5-7, W9, W13, W16-17) including a military issue Second

170 World War Moeris. The latter is marked ATP (Army Timepiece) with the UK forces board arrow mark. One US made wristwatch (W12) and three US made dials (W3-4, W8) were assessed for comparison, as was a 1920s US made Ingersoll Wrist (the precursor to modern style wristwatches). ii) Experimental methods.

The radium dial watches were surveyed using a portable mini-rad series 1000 dose rate monitor. Additionally, one First World War pocket compass was assessed for comparative purposes. Ambient dose rates $\left(\mu \mathrm{Sv} \mathrm{h}^{-1}\right)$ were measured at a distance of $2 \mathrm{~cm}$ between detector and watch or compass face. These measurements may include the effects of beta radiation in the vicinity of the watches and therefore may only be considered indicative readings. An estimate of the radium content of these items, was obtained by using a mini-rad 1000 to measure ambient equivalent gamma dose rates from three nominally $5 \mu \mathrm{Ci}(185 \mathrm{kBq})$ Panax

\footnotetext{
${ }^{226} \mathrm{Ra}$ sources. These sources comprise an active component (a radioactive foil) in a cup-type
} 
holder with an outer wire mesh (see Whitcher, 2009, Figure 1 and 2). Our measurements yielded, for our geometry, an estimated radium content calibration factor of $0.625 \mu \mathrm{Ci} / \mathrm{mrem}(2.31 \mathrm{kBq} / \mu \mathrm{Sv})$.

Laboratory based gamma and alpha spectrometry systems were employed to qualitatively confirm that the main radionuclide content of the watch dials was ${ }^{226} \mathrm{Ra}$. Due to the geometry of the alpha spectrometer's vacuum chamber only unmounted dials could be analysed using this approach.

A phantom was also utilised in the form of a $10 \mathrm{~cm}$ wide flat sided container with rounded edges (chosen to mimic the size of a human arm). This was filled with water and sealed with a cap, a TLD was attached to one side, and a watch the other (in this case a Buren Grandprix pocket watch, P1, see Table 3), facing inwards in order to be consistent with other measurements made. The use of a phantom was stimulated by the work of Klein et al. (1970) and Eikodd et al. (1961, see their Figure 1) who used paraffin wax based phantoms. Modern phantoms are typically made of slabs of anthropomorphic tissue-mimicking materials although water-based phantoms have also been used. The TLD used in this study was a body thermoluminescence Dosemeter supplied by the UK Health Protection Agency which use two dosed pellets of lithium fluoride ( $\mathrm{LiF}: \mathrm{Mg}, \mathrm{Cu}, \mathrm{P})$. The TLD consists of a polypropylene holder with a thick filter of PTFE and polypropylene covering a TLD element (used to assess dose from strongly penetrating radiation) together with a circular window positioned over a thinner TLD element covered by a thin layer of PTFE (used to assess both weakly and strongly penetrating radiation). They are used to assess dose to the whole body and the skin from x-rays, gamma and beta radiation. The detector has a dose range of $0.02 \mathrm{mSv}$ to $10 \mathrm{~Sv}$ and according to the HPA the detector is designed to absorb radiation in the same way and the same extent as human tissue (see 

accessed $29^{\text {th }}$ February, 2011). An assessment of the leakage of radon gas from the pocket and wrist watches was carried out using CR 39 detectors. A pocket watch and a wristwatch were each placed in two separate sealed containers for 2 hours together with the detectors. The CR39 detectors were then left in the container for a further 22 hours. A third identical container was used without a watch but with a CR39 detector present in it for 24 hours, to act as a control. The containers were glass Kilner jars of dimensions $10 \mathrm{~cm}$ (diameter) by $18 \mathrm{~cm}$ (height) and sealed with metal clips and a rubber ring. The watches were attached with Blutack to the top of the glass with the CR39 detectors at the base. The detectors were then processed using standard techniques (see Gillmore and Jabarivasal, 2010). Variations on this experiment were tried, one being leaving the watch in the chamber for 24 hours, and another was removing the pocket watch, and installing the CR39 detector for a further 24 hours. In order to confirm these results a Sarad Doseman was placed in a $20 \mathrm{~cm}$ diameter spherical glass desiccation chamber together with a pocket watch and measurements $\mathrm{s}$ were taken with and without the watch present.

In order to investigate any radon hazard potentially experienced by watch collectors, all the watches were placed in a box, volume $0.011 \mathrm{~m}^{3}$, in an actively ventilated room, volume 67.32 $\mathrm{m}^{3}$, to which access was restricted, with the atmospheric radon concentration monitored using a Durridge RAD7 real-time radon monitor. The ventilation regime operates continuously at a high rate all-day Monday-Friday but switches between this and reduced rates during Saturday-Sunday as determined by a variety of parameters. Such a ventilated room was

227 chosen following the observation of high radon concentrations arising from individual watches (see Results) to avoid placing people at otherwise avoidable risk, however minimal that risk might be. Furthermore, in order to minimise plate-out of radon daughters onto room 
surfaces the box was placed directly below a ventilation outlet. Following these initial experiments, a wipe-test of the room was undertaken to ascertain if there was any residual plated-out radioactive material which would require remediation. The wipe-test was below detectable limits but a consequence of these precautions is that it was not possible to measure the radon equilibrium concentration arising from the presence of the watches.

\section{Results.}

\section{i) Radium}

Dose rate data are presented in Tables 3 and 4, for pocket and wrist watches respectively. The Moeris pocket watch (P12) gave the highest readings, whether measured from the front or back; of $30 \mu \mathrm{Sv} \mathrm{h}^{-1}$ and $17 \mu \mathrm{Sv} \mathrm{h}^{-1}$ respectively with the mini-rad monitor. The Ingersoll pocket watches (P6-P9) are closely grouped, 7-10 $\mu \mathrm{Sv} \mathrm{h}^{-1}$ and 4.5-6 $\mu \mathrm{Sv} \mathrm{h}^{-1}$ front and back respectively. The two Buren pocket watches $(\mathrm{P} 1, \mathrm{P} 2)$ are also similar to each other but the two Ingraham pocket watches (P10, P11) are different, P10 measuring ca. 5 times $\mathrm{P} 11$. The Ingraham watches are "dollar watches" and the difference between these two watches, compared to the consistency amongst the more expensive watches from Buren and Ingersoll, suggests lower levels of quality assurance as might be expected.

The Moeris wrist watch (W13) gives the highest dose rates amongst the wrist watches, whether measured from the front or back; $20 \mu \mathrm{Sv} \mathrm{h}^{-1}$ and $14 \mu \mathrm{Sv} \mathrm{h}^{-1}$ respectively. This, however, is atypical being 4-5 times higher than the next highest wrist watches. More typically, wrist watches are 6-7 times less radioactive than pocket watches but military issued wrist watches (e.g. W13) give rise to significantly higher readings than wristwatches supplied to the public, being closer to the readings taken from the pocket watches. 
For both pocket and wrist watches, the dose rates measured at the front of the watches are typically about $70-71 \%$ greater than those measured at the back, due mainly to the greater attenuation of the emitted beta radiation by the watch movement and rear metal case compared to the glass and bezel at the front. The wrist watches are more variable in this respect. Further evidence of such attenuation is afforded by one of the Buren pocket watches (P1) which had a travel case: when the watch was inside this case it gave similar dose rates of ca. $16 \mu \mathrm{Sv} \mathrm{h}^{-1}$ both front and back. Similarly, the Waltham pocket watch (P14) was also measured with the glass removed, which gave a reading of $18 \mu \mathrm{Sv} \mathrm{h}^{-1}, 5 \mu \mathrm{Sv} \mathrm{h}^{-1}$ greater than when the glass was in place.

This increased hazard arising from removal of the bezel and glass is noteworthy, as they were very easily detached in some watches. The ambient dose rate at $2 \mathrm{~cm}$ for the pocket compass (PC) was $20 \mu \mathrm{Sv} \mathrm{h}^{-1}$ with the cover open, and 17-18 $\mu \mathrm{Sv} \mathrm{h}^{-1}$ with the cover closed. The brass and nickel plated cover therefore providing little shielding. This compass would have been worn in a similar way to pocket watches and thus give rise to a comparable hazard.

In order to confirm the type of radioactivity present in the watch dials W3-4 were placed in both the laboratory based alpha spectrometer and the gamma spectrometer, as was the Hamilton dial (measured as $0.5 \mu \mathrm{Sv} \mathrm{h}^{-1}$ ). The acquired alpha spectra had four distinct alpha particle energy peaks which were identified as representing alpha emission from ${ }^{226} \mathrm{Ra},{ }^{222} \mathrm{Rn}$,

${ }^{218} \mathrm{Po}$ and ${ }^{214} \mathrm{Po}$ in the ${ }^{238} \mathrm{U}$ decay series. The gamma ray spectra confirmed the presence of ${ }^{226} \mathrm{Ra}$ decay series isotopes.

\section{ii) Radon}

Following the initial observations of alpha particles at energies corresponding to those for ${ }^{222} \mathrm{Rn}$ alpha emissions, the extent of ${ }^{222} \mathrm{Rn}$ leakage from complete wristwatches was also 
investigated using the alpha spectrometer. The Newmark wrist watch (W14) that had the

277

278

280

281

282

283

284

285

lowest radioactivity level was placed in the alpha spectrometer chamber. Alpha particles at energies corresponding to ${ }^{222} \mathrm{Rn}$ were observed, indicating the escape of radon into the surrounding environment from the watch (there being no detectable radiation with no watch present in the chamber). This has previously been highlighted by Boerner and Buchholz (2007).

The CR39 detectors placed in the sealed containers with watches confirmed radon gas leakage from the watches yielding radon concentrations higher than the maximum resolvable. The detector placed with the pocket watches was overwhelmed by alpha particle strikes and the detector surface was saturated with irresolvable overlapping tracks, as shown in Figure 3. Similar results were obtained for all variations of this experiment, necessitating a different approach via Sarad Doseman which recorded an average radon concentration of $18,728 \mathrm{~Bq}$ $\mathrm{m}^{-3}$ over a 48 hour period from Helvetia pocket watch P5 placed in the sealed chamber.

The preliminary watches-in-room experiment was over a 16 hour period. This highlighted that atmospheric radon as measured with a RAD7 was elevated by the presence of the watches by a significant amount, i.e. from an empty-room average of $1.02 \mathrm{~Bq} \mathrm{~m}^{-3}$ (with a maximum of $5.44 \mathrm{~Bq} \mathrm{~m}^{-3}$, over 24 hours), to an average of $259 \pm 9 \mathrm{~Bq} \mathrm{~m}^{-3}$ (with a maximum of $319 \pm 31 \mathrm{~Bq} \mathrm{~m}^{-3}$ ) in the 16 hour period.

The more detailed watches-in-room experiment was conducted over two 3-week periods in May-July 2011, between which the ventilation system changed from term-time to summer vacation regimes. The RAD7 data are shown in Figure 4, and the basic weekday-weekend cycle is apparent in both periods. During the week, the ventilation system operates at the full, high rate, and this keeps the radon concentrations down to $190-290 \mathrm{~Bq} \mathrm{~m}^{-3}$. During the 
weekends, and particularly on Sundays, the ventilation system switches to a modulated on-off regime giving rise to an effective lower ventilation rate, and radon concentrations rose sharply to ca. 2,000 $\mathrm{Bq} \mathrm{m}^{-3}$ or more during such periods (with a maximum of 3,260 $\pm 96 \mathrm{~Bq}$ $\mathrm{m}^{-3}$ during July 2011) before falling sharply to the weekday concentrations as the continuous higher ventilation resumes on Mondays. Also, during the second period, there is evidence that the ventilation system switches to a modulated on-off regime during (some) weeknights, giving rise to 24-hour cyclic features in the data.

Assuming that the total inferred radium content gives rise to radon, all of which escapes from the watches, it is possible to estimate total radon activity and from there the radon concentration in the room. This yields an estimate of ca. $6 \mathrm{kBq} \mathrm{m}^{-3}$ assuming volumetric uniformity throughout the room. However, it should be noted that this assumption takes no account of air circulation and the ventilation system and, therefore, the concentrations recorded by the RAD7 do not necessarily linearly correspond to this estimate. In light of this, whilst it is possible in principle to estimate the radon equilibrium concentration for the effective sub-volume monitored by the RAD7 from the data shown in Figure 4, the variation in the ventilation regime complicates such estimates. However, initial simulations suggest that the equilibrium concentration in this sub-volume may exceed $10 \mathrm{kBq} \mathrm{m}^{-3}$, higher than the radium-derived estimate (although only pertaining to the immediate volume surrounding the box and RAD7). The difference between the two estimates is attributed in large part to the to the uncertainties in the uniformity of the radon measurement resulting from the safety considerations of this preliminary investigation. Further experimental (and theoretical) work on that actual radon emanation from the watches is underway, with an initial update to be 
Crockett, 2012). However, even the lower radium-derived estimate is ca. 30 times the UK

Domestic Action Level: as a concentration inferred from an amount of radioactivity entering

324

a larger volume than would typically house private collections, this implies higher concentrations could arise from similar private collections.

The radon emission, and other radioactivity, are confirmed by the results of gamma ray spectrometry, as illustrated in Figure 2 for pocket and wrist watches respectively. These show the emission of gamma rays at $186 \mathrm{keV}$ from ${ }^{226} \mathrm{Ra}$, which then decays into short-lived decay products with similar activity, emitting alpha, beta and gamma radiation.

The TLD used in this study for the phantom experiment is really designed to measure radiation from a source some distance away, rather than a nearby source, so interpreting the result (and converting it to the geometry we are using) is problematic. Bearing this in mind, this experiment suggested a skin dose rate of $0.375 \mu \mathrm{Sv} \mathrm{h}^{-1}$, results being reported by the HPA as $0.36 \mathrm{mSv}$ for the 40 days exposure.

\section{Discussion.}

The above results can be compared to research published in the 1970s (NCRP, 1977) showing that wearing pocket watches could be a health risk, the NCRP report highlighting a risk to wearers' gonads. Robinson (1968) estimated the average gonadol dose-equivalent rate was 3 $\mathrm{mrem} / \mathrm{y}(0.03 \mathrm{mSv} / \mathrm{y})$ for each of the 10 million people in the USA who wore such watches, with individual dose rates being as high as $310 \mathrm{mrem} / \mathrm{y}$ (or $3.1 \mathrm{mSv} / \mathrm{y}$ ) for one wearer of a wristwatch which contained $4.5 \mu \mathrm{Ci}(167 \mathrm{MBq})$ of ${ }^{226} \mathrm{Ra}$. Klein et al. (1970), using a phantom, estimated a gonadol dose-equivalent rate of $60 \mathrm{mrem} / \mathrm{y}$ (or $0.6 \mathrm{mSv} / \mathrm{y}$ ) per $\mu \mathrm{Ci}$ (37 $\mathrm{MBq}$ ) of ${ }^{226} \mathrm{Ra}$ based on 16 hours per day wear. However, it might be useful to also note that 
McCarthy and Mejdahl (1963) found that 50\% of the subjects in their study wore

wristwatches continuously.

347 Eikodd et al. (1961) illustrated isodose curves in a phantom exposed to a wristwatch with one $\mu \mathrm{g}$ of radium. They demonstrated that dose decreases away from the watch so that $3 \mathrm{cms}$ away from the watch inside their phantom the dose rate was around $0.6 \mathrm{mrad} \mathrm{h}^{-1}\left(6 \mu \mathrm{Gy} \mathrm{h}^{-1}\right)$. Boerner and Buchholz (2007) presented nine exposure scenarios to assess potential dose from radium-containing timepieces. Two of these scenarios, Scenario 1 (dose to the skin from wearing a ${ }^{226} \mathrm{Ra}$ timepiece) and Scenario 2 (dose to self from wearing such a timepiece) formed the basis for the current study. In Scenario 1, Boerner and Buchholz (2007; after Klein et al., 1970) estimated shallow-dose equivalent to the skin of an individual who wears a wristwatch for 16 hours a day at 1,600 mrem/y (16 mSv/y). In Scenario 2, assuming that each watch contained $1 \mu \mathrm{Ci}(37 \mathrm{MBq})$ of ${ }^{226} \mathrm{Ra}$, Boerner and Buchholz (2007) calculated dose equivalents of $110 \mathrm{mrem} / \mathrm{y}(1.1 \mathrm{mSv} / \mathrm{y})$ and $480 \mathrm{mrem} / \mathrm{y}(4.8 \mathrm{mSv} / \mathrm{y})$ for a person wearing a pocket watch in a trouser or vest pocket respectively, and $61 \mathrm{mrem} / \mathrm{y}(0.61 \mathrm{mSv} / \mathrm{y})$ for a person wearing a wristwatch. To calculate dose to skin from a wristwatch Boerner and Buchholz (2007) utilised the formula: Skin dose $=\mathrm{A} \times \mathrm{DCF}_{\mathrm{c}} \times \mathrm{T}$, where $\mathrm{A}$

$=$ Total Source Activity $(\mu \mathrm{Ci})$,

The amount of radium used in watches varies, as do the thicknesses of cases, internal workings and watch-glasses. These variations in construction mean that providing a general statement on risks for wearers is difficult. Hence, in this study, we have assessed (partly via the above scenarios) our own collection of watches. Another issue to highlight is that 
condition affects radioactivity levels, again variably, but in general terms the better the condition the higher the dose-rate (due, presumably, to watches in poorer condition having lost paint particles through relative ill-use). The two Buren pocket watches (P1-2), which have different ambient equivalent dose rate outputs (see Table 3), provide a good example of these variations. The good condition watch (P1) gave a dose rate of $22 \mu \mathrm{Sv} \mathrm{h}^{-1}$, whilst the poorer condition watch (P2) gave rise to $18 \mu \mathrm{Sv} \mathrm{h}^{-1}$ (see Tables 1 and 3). It is also important to highlight the difference in radioactivity between the military issue pocket watches (which were sold to the public as surplus stock after the Second World War, now very popular collectors' items) and the others examined in this study. As a general rule, military watches produced ambient equivalent dose rates at least twice that of non-military watches. In our study, the data show that all the military pocket watches would give rise to a significant effective body dose after only a week of wearing. Another hazard to collectors (and repairers), particularly with poorer-condition watches with damaged paint, is the risk of ingestion (and inhalation) of degraded and flaked paint when opening the case or removing the glass (Walker, 2010). The HSE (2002) highlighted controls on timepieces containing radioactive substances for those in the retail and antique trade, noting that they were no longer free to dispose of damaged luminised clocks and watches with general refuse (96/29/EURATOM). Whilst Shaw et al. (2007) noted that regulation of radium timepieces or 'historic products' sold in antique markets and the internet was "impossible", they also suggested that the number of such products still in circulation was "assumed to be very small". This, in our view could be highly misleading, as such watches are relatively common on sites such as eBay, as our research for this work has shown.

The UK Ionising Radiation Regulations (1999) established annual dose limits for people working with, or exposed to, ionising radiation in the workplace. The annual whole body 
dose limit is $1 \mathrm{mSv}$ for the general public, and our analysis suggests that regularly wearing the most active of these pocket watches in a chest pocket can exceed this annual limit. Following the scenarios suggested by Boerner and Buchholz (2007) we estimated maximum effective annual doses of $5.1 \mathrm{mSv}$, and $1.169 \mathrm{mSv}$ if such a pocket watch was worn in chest or trouser pockets respectively, with a skin dose maximum of $16 \mathrm{mSv}$ (see Table 3). These assumes exposure from the back of the watch: if a pocket watch was carried with the glass facing inwards, the doses received would be higher as we observed front-face dose rates to be ca. $70 \%$ higher than those from the back. Where wristwatches are concerned the maximum skin dose was $14 \mathrm{mSv}$ with $4.2 \mathrm{mSv}$ effective dose in vest pocket (see Table 4).

Collectors (and others) who wear radium-painted watches continue to expose themselves to risk. Collectors might not wear these watches continuously, thus reducing their exposures and risks, but might also vary the watches (from their collections) that they wear, varying their exposures and risks correspondingly. It should be noted that in general, wrist-watch wearers will have longer exposure times and some people do not remove wrist-watches at night. Thus, despite the generally lower wrist-watch dose rates, the overall dose might be higher than indicated above due to wrist-watches being worn for more than 16 hours / day. Furthermore, in light of the radon results, it would highly inadvisable to sleep wearing such a watch with the possibility that the watch-bearing wrist - where the radon will be most concentrated - can be very close to the wearer's nose and mouth for extended night-time periods exposing the wearer to significantly increased inhalation of radon (and daughters).

The radon emissions from radium paint have remained relatively less known and understood than the radium itself and thus are potentially of more concern, particularly to collectors of watches (and other uranium and radium containing articles). As described above, conservative and precautionary measurements of radon arising from a notional collection of 
41715 pocket watches, 18 wrist watches and a couple of miscellaneous items indicate that radon concentrations routinely exceed the UK HPA/NRPB Domestic Action Level of $200 \mathrm{~Bq} \mathrm{~m}^{-3}$ under conditions of high ventilation, rising to over 10 times that Action Level at lower ventilation rates. Private collectors might, typically, keep their collections in (small) rooms in houses, possibly secured (and possibly unventilated) from the surroundings, or in sealed cabinets, and in either situation expose themselves to very high concentrations of radon when in the presence of their collections. The risk to themselves will depend on the time they spend with their collections, as well as the amounts of radioactive material in their collections, but collectors also have a duty of care for the risk to any visitors, particularly visitors who are not fellow collectors.

Average radon concentrations in radium dial factories was estimated by Rowland (1994) as $1,887 \mathrm{~Bq} \mathrm{~m}^{-3}$. Storage of military surplus commodities containing radium was noted as a concern by Halperin and Heslep (1966), who suggested that some stores had thousands of radioactive switches, circuit breakers, meters etc., one Japanese meter containing $14.6 \mu \mathrm{g}$ of ${ }^{226} \mathrm{Ra}$. Radon in such environments must have been elevated as a result. Blaufox (1988) highlights a case where a carton of 100 compasses in military storage contained $267 \mathrm{nCi}$ $(9,879 \mathrm{~Bq})$ of radon. Our tests for radon demonstrate that a collection of watches with radium based paint can raise radon concentrations in a room where no radon was previously recorded. It is significant that the average concentration in this continuously actively ventilated room rose from negligible to over $200 \mathrm{~Bq} \mathrm{~m}^{-3}$, peaking at over $3000 \mathrm{~Bq} \mathrm{~m}^{-3}$ when the air circulation systems operated at reduced rates. These results are comparable to radon concentrations recorded in caves; Sperrin et al. (2001) noted a high of 2,600 $\mathrm{Bq} \mathrm{m}^{-3}$ in UK caves in Carboniferous Limestone; Gillmore et al. (2002) recorded up to 7,800 $\mathrm{Bq} \mathrm{m}^{-3}$ in a 
440 Permian Limestone cave system in the UK; Gillmore et al. (2005) recorded radon

441 concentrations up to $3,075 \mathrm{~Bq} \mathrm{~m}^{-3}$ in a cave in Subis Limestone in Malaysia.

442 This initial investigation of radon arising for radium-painted watches has indicated a

443 significant hazard arising from comparatively small collections, and this investigation will be 444 extended in future projects.

\section{Conclusion}

447 Our research has confirmed that radium dial watches individually are a modest health risk to wearers. It would seem prudent therefore to apply the ALARA or ALARP principles.

449 Significantly, there is also a risk to amateur collectors from radon gas emitted from the 450 radium. Routine radon concentrations of ca. $200 \mathrm{~Bq} \mathrm{~m}^{-3}$, i.e. the UK Domestic Action Level, 451 peaking to over $3 \mathrm{kBq} \mathrm{m}^{-3}$, were recorded in this study: such levels represent a significant 452 potential health hazard. Those peak levels accord with the estimated equilibrium 453 concentration of ca. $6 \mathrm{kBq} \mathrm{m}^{-3}$ derived from the inferred radium content. Also, it should be noted that the room volume of approximately $67 \mathrm{~m}^{-3}$ is likely to be considerably larger than the volume of a typical private collector's storage space, implying higher concentrations would have been observed in such circumstances. There are considerable numbers of radium watches that remain in circulation and these are readily collectible being easily obtained through sites such as eBay.

Other instruments also need to be considered, such as compasses (our work here includes a

461 First World War pocket compass) and aircraft dials which also remain in circulation. A large compass was donated to the HPA, which when placed into their radon chamber gave rise to 
463 readings of $14,000 \mathrm{~Bq} \mathrm{~m}^{-3}$ (Miles pers comm., 2008). Other artefacts should also be noted

464 that contained radioactive materials, as identified by Blaufox (1988), such as dinnerware,

465 rings, and scientific instruments.

467 In addition, in the UK, according to Harvie (2005), there may be many sites contaminated by 468 radium that have not been remediated as there were, during the height of production, no 469 planning controls and limited safety and occupational health procedures. A DEFRA report 470 produced by Entec Ltd in 2004 suggested in contrast that many UK sites were known, 471 however, Blyth Brooke (1960) points out that there were many small factories and home workshops producing luminised products in conditions that were of concern, with workers paying little regard to spillage and appropriate disposal of waste. Baker and Toque (2005)

474 point out that luminised instruments and paint were disposed of by burning and burial at a number of Ministry of Defence sites in the UK. This practice also occurred on waste ground near commercial factories (see Blyth Brooke, 1960). In December 2011 the website defence management (http://www.defencemanagement.com) stated that the MOD had identified 15 UK radium contaminated sites, 12 of which had not previously been identified, following Freedom of Information (FOI) requests (see FOI request reference 18-10-2011-171421-021). One well known site at Dalgety Bay (Hitchin and Sinclair, 2010) has led the MOD to spend $£ 750,000$ to protect a nearby housing estate. There is a need in the authors view to acknowledge that health risks associated with radium artefacts is a serious issue. The results presented in this study may in fact be just the tip of the iceberg. The risks of radioluminescent materials has been largely forgotten as most modern 
486 materials are much less radiotoxic because each isotope emits only low energy beta, being 487 based on tritium $\left({ }^{3} \mathrm{H}\right)$ or promethium $\left({ }^{147} \mathrm{Pm}\right)$ particles, or even non-radioactive luminous 488 material (e.g. 'Lumibright'). This suggests that more publicity to emphasise the risks would 489 be an appropriate course of action.

\section{Acknowledgments.}

492 We would like to thank Dr Paul Frame, Oak Ridge Associated Universities, Tennessee, USA 493 for helpful comments made on an earlier version of this manuscript, and the Kingston 494 University cartographer Claire Ivison for work on the figures. We would also like to 495 acknowledge UNESCO/IUGS IGCP Project 571 for facilitating the later stages of this 496 research. 
Baker, A.C., Toque, C., 2005. A review of the potential for radium from luminising activities to migrate in the environment. Journal of Radiological Protection, 25, 127-140.

BEIR IV, 1988. Health Risks of Radon and Other Internally Deposited Alpha-Emitters.

Bizony, P., 2007. Atom. Icon, Cambridge, UK.

Blaufox, M.D., 1988. Radioactive artifacts: Historical sources of modern radium contamination. Seminars in Nuclear Medicine, 18, 46-64.

Blyth Brooke, C.O.S., 1960. Radiation Hazards in the Distribution and Use of Luminizing

Compounds. Royal Society for the Promotion of Health, 80, 228-231.

Boerner, A.J., Buchholz, M.A., 2007. Radium Timepiece Dose Modelling. Oak Ridge Institute for Science and Education, Oak Ridge, Tennessee, USA. DE-AC05-06 OR23100 for the US Nuclear Regulatory Commission.

Bruenger, F.W., Lloyd, R.D., Miller, S.C., Taylor, G.N., Angus, W., Huth, D.A., 1994.

Occurrence of Mammary Tumors in Beagles given Radium-226. Radiation Research, 138, $512 \quad 423-434$.

Bruton, E., 2002. The history of clocks and watches. Time Warner Books, London.

514 Cameron, A.T., 1912. Radium and Radioactivity. Society for Promoting Christian

515 Knowledge, London, New York. Reprinted by Kessinger Publishing.

516 Eikodd, A., Reistad, A., Storruste, A., Synnes, J., 1961. Radioactivity of Luminous Watches 517 and Estimation of Dose to the Wrist and Gonads. Physics in Medicine and Biology, 6, 25-31. 
518 Evans, R.D., 1966. The effect of skeletally deposited alpha-ray emitters in man. British 519 Journal of Radiology, 39, 881-895.

520 Gillmore, G., Phillips, P., Denman, A., Gilbertson, D.D., 2002. Radon in the Creswell Crags 521 Permian Limestone caves. Journal of Environmental Radioactivity, 62, 165-179.

522 Gillmore, G.K., Gilbertson, D., Grattan, J., Hunt, C., McLaren, S., Pyatt, B., mani Banda, R., 523 Barker, G., Denman, A., Phillips, P., Reynolds, T., 2005. The potential risk from 222radon 524 posed to archaeologists and earth scientists: reconnaissance study of radon concentrations, 525 excavations, and archaeological shelters in the Great Cave of Niah, Sarawak, Malaysia.

526 Ecotoxicology and Environmental Safety, 60, 213-227.

527 Gillmore, G.K., Jabarivasal, N., 2010. A reconnaissance study of radon concentrations in 528 Hamadan city, Iran. Natural Hazards and Earth System Science, 10, 857-863.

529 Gillmore, G.K. and Crockett, R.G.M., 2012. Radon Emissions from Radium-Dial Watches. 530 Geophys. Res. Abstr., Vol. 14, EGU2012-9044, EGU General Assembly, Vienna, April 5312012.

Halperin, J.A., Heslep, J.M., 1966. Radium in Military Surplus Commodities. Public Health 533 Reports, 81(12), 1057-1063.

Harvie, D.I., 2005. Deadly Sunshine: The History and Fatal Legacy of Radium. Tempus, Stroud, UK.

HELA (Health and Safety Executive / Local Authorities Enforcement Liaison Committee), 2001. Hazards from luminised timepieces in watch / clock repair. Local Authority Circular, 42/6, UK.

Hitchin, G., Sinclair, P., 2010. Defence Estates Dalgety Bay Radiological Support. 
541 HSE (Health and Safety Executive), 2002. Radiation Protection News. Issue 21, May 2002.

542 IAEA (International Atomic Energy Agency), 1967. Radiation Protection Standards for

543 Radioluminous Timepieces - Recommendations of the European Nuclear Energy Agency

544 and the International Atomic Energy Agency, IAEA Safety Series No. 23.

545 Klein, H.F., Robinson. E.W., Gragg, R.L., Rolofson, J.W., 1970. Evaluation of emissions

546 from radium watch dial watches. Radiological Health Data Report, 11, 7-9.

547 McCarthy, R., Mejdahl, V., 1963. The Genetically Significant Radiation Dose from

548 Luminous Wrist Watches. Physics in Medicine and Biology, 8, 279-285.

549 Martland, H.S., Humphries, R.E., 1973. Osteogenic Sarcoma in Dial Painters using

550 Luminous Paints. CA Cancer Journal for Clinicians, 23, 368-374.

551 National Council on Radiation Protection and Measurements, 1977. Radiation exposure from

552 consumer products and miscellaneous sources. NCRP Report 56, Washington D.C., USA.

553 ODA (Olympic Delivery Authority), 2007. Olympic Park Construction Zone 6A. Review of 554 procedures relating to the discovery of radioactive substances. Report ATK-CM- $06^{\mathrm{a}}-$ 555 ZZZZZZ-0002, Epsom, UK.

556 Robinson, E.W., 1968. The use of radium in consumer products. HEW Report MORP 68-5, 557 Rockville, USA.

558 Rowland, R.E., 1994. Radium in Humans. A Review of US Studies. Argonne National 559 Laboratory, ANL/ER-3, UC-408, Illinois, USA. 
560

561

562

563

564

565

566

567

568

569

570

571

572

573

574

575

576

577

578

579

580

581

Schlundt, H., 1931. The Refining of Mesothorium. Journal of Chemical Education, 8(7), 1274-1287.

Shaw, J., Dunderdale, J., Paynter, R.A., 2007. Radiation Protection 147. Guidelines for the Regulatory Control of Consumer Products Containing Radioactive Substances in the European Union. Directorate-General for Energy and Transport Directorate H - Nuclear Energy Unit H.4 - Radiation Protection.

Sperrin, M., Gillmore, G., Denman, T., 2001. Radon Concentration Variations in a Mendip Cave Cluster. Environmental Management and Health, 12, 476-482.

Stehney, A.H., 1995. Health Studies of U.S. Women Radium Dial Workers. In: Young, J.P., Yalow, R.S. (Eds.), Radiation and Public Perception. Benefits and Risks. American Chemical Society Advances in Chemistry, 243, 169-200.

Wertheim, D., Gillmore, G., Brown, L., Petford, N., 2010. 3-D imaging of particle tracks in solid state nuclear track detectors. Natural Hazards and Earth System Science, 10, 1033-1036.

Wesolowski, Z.M., 2006. A concise guide to military timepieces, 1880-1990. Crowood Press, Marlborough, UK.

Whitcher, R., 2009. The long-term safe condition of sealed radioactive sources in schools. School Science Review, 90(232), 113-121.

Figure 1.

A photograph of a selection of pocket and wristwatches assessed for this study. Of the three pocket watches, one was Swiss made (Buren, P1) and military issue, one was US made (Ingraham, P11) and one UK made (Ingersoll, P9). Of the wristwatches one was US made (Ingraham, W12), the other two are UK (Newmark, W14, W15). The right hand wristwatch 
582 (W15) gave rise to an ambient dose reading of $4.5 \mu \mathrm{Sv} \mathrm{h}^{-1}$, whilst the Buren pocket watch

583 (P1) gave one of the highest dose readings for such a watch in this study at $22 \mu \mathrm{Sv} \mathrm{h}^{-1}$. Note 584 the faded and flaked paint of the central Newmark watch (W14).

585 Figure 2.

586 Laboratory based gamma spectrometry of the Newmark (W1) wrist watch and Buren (P1)

587 pocket watch. Note the peaks at energies characteristic of the gamma radiation from ${ }^{226} \mathrm{Ra}$, $588 \quad 214 \mathrm{~Pb}$ and $214 \mathrm{Bi}$.

589 Figure 3.

590 View of two CR39 detector surfaces taken with an Olympus LEXT OLS4000 series laser 591 scanning confocal microscope, after Wertheim et al. (2010). 2D images with 10X objective. 592 Top image of detector exposed for 48 hours in enclosed chamber with the Helvetia pocket 593 watch, bottom one exposed to a Newmark wristwatch.

594 Figure 4.

595 RAD7 plots for indoor radon concentrations in a room containing the watch collection for 596 two 3-week periods in May-July 2011. Note the peaks on Sundays (and also smaller peaks 597 on some Saturdays).

598 Table 1

599 Pocket watch codes and notes.

600

601 Table 2. 
Wristwatch codes and notes.

603

604 Table 3.

605 Results of pocket watch and compass testing. Results are for a Series 1000 mini-rad and a 606 TLD phantom experiment. Estimates of radium content are based on dose rate from Panax

$607{ }^{226} \mathrm{Ra}$ sources as a comparison. Skin dose at wrist, effective dose in vest and trouser pockets 608 based on scenarios presented by Boerner and Buchholz (2007). Arithmetic and geometric 609 means exclude the pocket compass (PC).

610

611 Table 4.

612 Results of wrist watch testing. Results are for a Series 1000 mini-rad. Estimates of radium

613 content are based on dose rate from Panax ${ }^{226}$ Ra sources as a comparison. Skin dose at wrist,

614 effective dose in vest and trouser pockets based on scenarios presented by Boerner and 615 Buchholz (2007). Arithmetic and geometric means exclude watch hands (WH).

616 
620 Figure 1
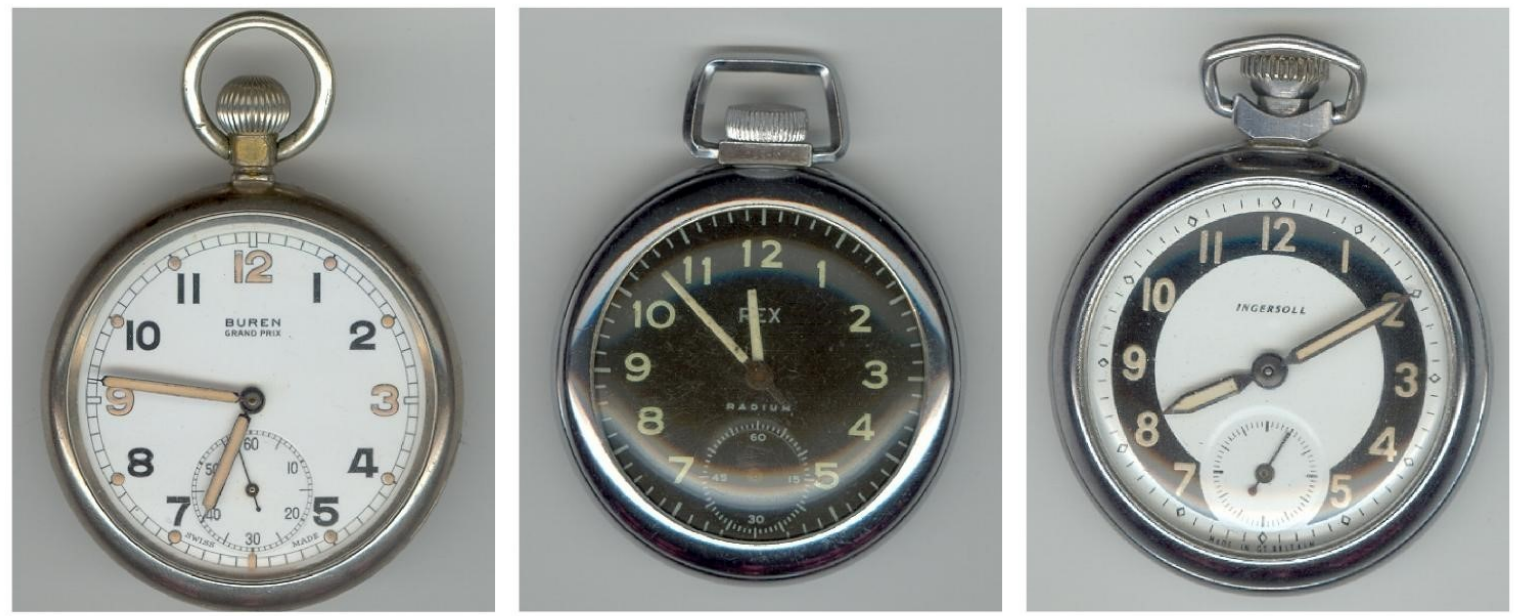

621

622
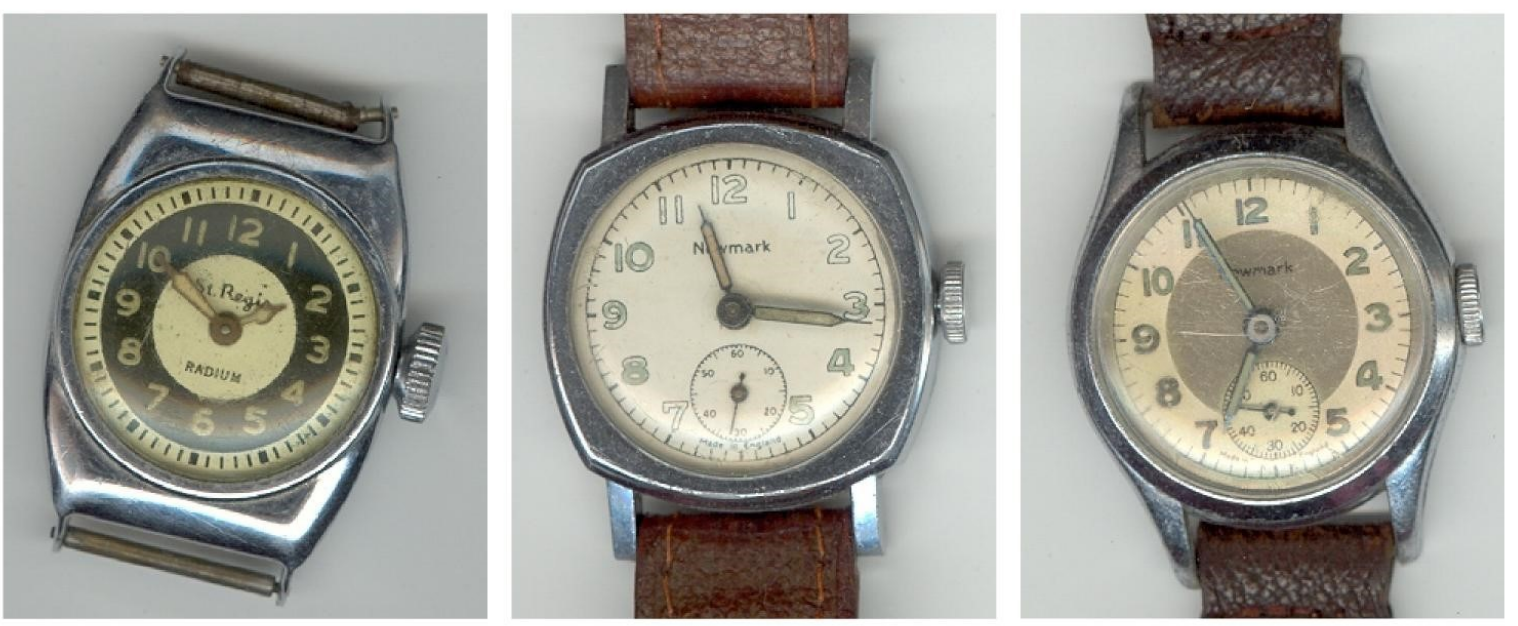

623

624

625 Figure 2 


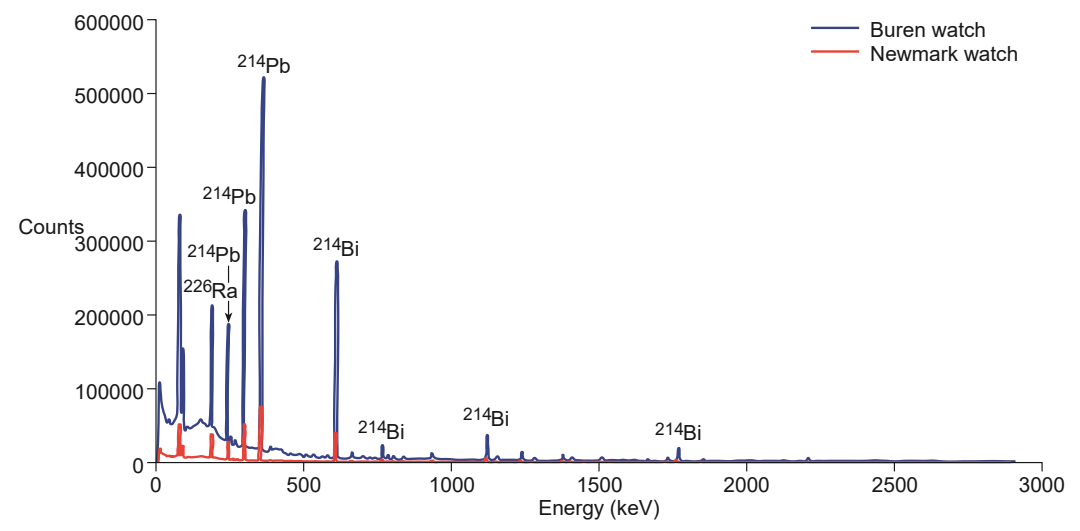

628 Figure 3 

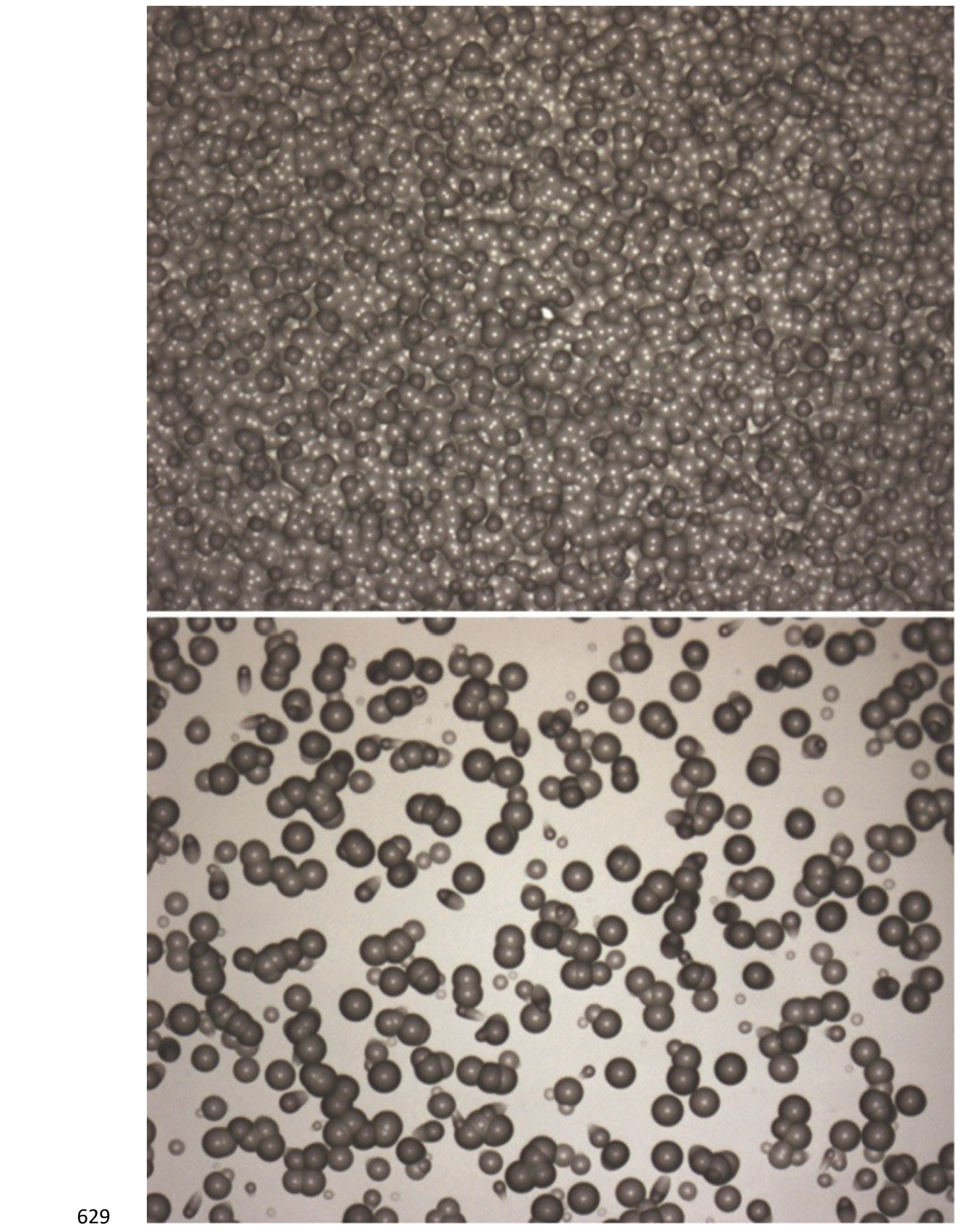
632 Figure 4

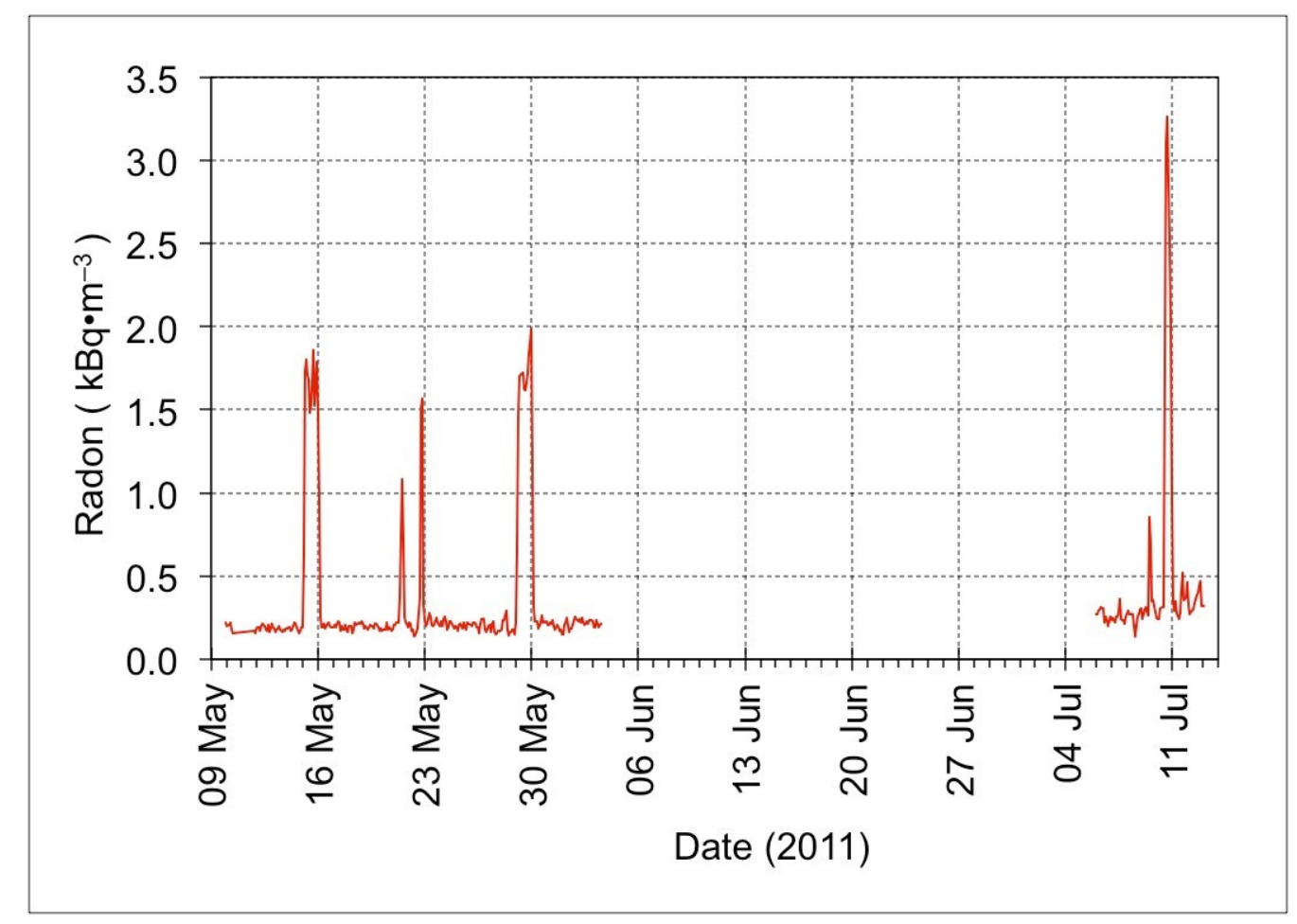

